\title{
Age estimation on long-beaked common dolphins, Delphinus capensis, from the Gulf of California
}

\author{
Juan Pablo Gallo-Reynoso ${ }^{1 *}$, Edna O. Francisco ${ }^{1,2}$ \\ y Charles Leo Ortiz ${ }^{3}$
}

Introduction: We estimated the age of 41 long-beaked common dolphins, Delphinus capensis, found stranded in Sonora and Baja California beaches in the Gulf of California from 1981 to 2000. The aim of our work was to know the age and if possible the size of stranded dolphins and the possible causes of their stranding.

Methods: Dentinal growth layers in teeth were revealed using an acid-etching technique; it involves preparation of half-etched teeth by grinding and polishing with sandpaper (220-600 grit) and demineralization in $5 \%$ formic acid. A stereo-microscope was used for counting annual growth layer groups (GLGs). Four different readers of dentinal layers assisted to obtain the estimate of age.

Results: Age category estimates were: 17 individuals were adults (12-21 GLGs), 10 individuals were subadults (7-12 GLGs), 10 individuals were juveniles (2-7 GLGs), and 4 individuals were nursing calves ( $<1$ GLG). 15 individuals were measured and sexed on the field ( 6 calves, 6 subadults and 3 adults). Larger dolphins were the older ones: the longest male of $264.7 \mathrm{~cm}$ presented $21 \mathrm{GLGs}$, and the longest female of $252.4 \mathrm{~cm}$ was $18 \mathrm{GLGs}$ (one GLG corresponding to one year). Independent of the sex of the dolphins, the regression of age on length was significant with an $r^{2}=0.7068, P<0.0001$.

Discussion: Age estimates can serve to know the vulnerability and incidence of long-beaked common dolphins of different ages due to toxic algae effects (Domoic acid) or to the biomagnification of man-made toxins used for agriculture, due to the ingestion of small pelagic fishes that accumulates these toxins. It also can provide insight in fishery interactions and mortality on D. capensis in the Gulf of California.

Key words: Age estimation, common strandings, Delphinus capensis, dolphins, Gulf of California, longbeaked.

\section{Resumen}

Se estimó la edad de 41 delfines comunes de rostro largo Delphinus capensis, encontrados varados en playas de Sonora y Baja California, entre 1981 y 2000 . El objetivo de nuestro trabajo fue el de conocer la edad y estimar la longitud estándar, y en lo posible conocer las causas del varamiento. El crecimiento de las capas de dentina en dientes fueron obtenidas a partir de la técnica de rebajado con ácido, lo cual involucra la preparación de los dientes desgastados hasta la mitad con lijado y Pulido con lijas (grano de 220-600) y desmineralización con ácido fórmico al 5\%. Se utilizó

\footnotetext{
${ }^{1}$ Centro de Investigación en Alimentación y Desarrollo, A. C. Unidad Guaymas. Laboratorio de Ecofisiología. Carretera a Varadero Nacional km 6.6. Las Playitas, Guaymas 85480, Sonora, México. E-mail: jpgallo@ciad.mx (JPGR)

${ }^{2}$ Woodman Ave. 9235- J, Arleta, CA 91331. United States. E-mail: efsalsababe@yahoo.com (EOF)

${ }^{3}$ University of California Santa Cruz. Earth and Marine Sciences A 308. 1156 High Street Santa Cruz, CA 95064. United States. E-mail: ortiz@biology.ucsc.edu (CLO)

*Corresponding author.
} 
un microscopio estereoscópico para contar los grupos anuales de capas de crecimiento (annual growth layer groups o GLGs). Cuatro diferentes lectores asistieron para obtener las estimaciones de la edad. Las categorías de edad estimadas fueron: 17 individuos eran adultos (12-21 GLGs), 10 individuos fueron subadultos (7-12 GLGs), 10 individuos juveniles (2-7 GLGs), y cuatro individuos fueron crías lactantes ( $<1$ GLG). Se obtuvieron las medidas y el sexado de 15 individuos en campo ( 6 crías, 6 subadultos y 3 adultos), los individuos más largos, fueron los más viejos: el macho más largo fue de $264.7 \mathrm{~cm}$ con 21 GLGs, y la hembra más larga con 252.4 cm con 18 GLGs (un GLG corresponde a un año). Independientemente del sexo de los delfines, la regresión de la edad sobre la talla fue significante con una $r^{2}=0.7068, P<0.0001$. La estimación de la edad puede servir para conocer la vulnerabilidad y la incidencia de la mortalidad a diferentes edades de los delfines comunes de rostro largo, debido por ejemplo a la mortalidad causada por efectos de algas tóxicas (ácido Domóico) debido a la ingesta de peces pelágicos menores que acumulan esas toxinas, o a la magnificación de toxinas hechas por los humanos y usadas en la agricultura. También puede proveer de información sobre las interacciones con las pesquerías y la mortalidad de $D$. capensis in el Golfo de California.

Palabras clave: delfines comunes de rostro largo, Delphinus capensis, estimación de edad, Golfo de California, varamientos.

Long-beaked common dolphin, Delphinus capensis, is the most common cetacean in the Gulf of California, with sightings in all seasons and throughout the entire Gulf (GalloReynoso and Alessio-Robles 1989; Gallo-Reynoso 1990; Gallo-Reynoso 1991; Vidal et al. 1993; Silber et al. 1994; Gallo-Reynoso 1998) with groups as large as 5,000 individuals (Gallo-Reynoso 1991). Much of the distribution of long-beaked common dolphins is over upwelling areas (Gallo-Reynoso and Alessio-Robles 1989; Gallo-Reynoso 1998), which influences the overall higher primary production rates of the Gulf of California (ÁlvarezBorrego 1983). This high primary production determines their prey distribution in coastal areas, consisting mainly of small pelagic species, such as sardines (Sardinops caeruleus), Pacific mackerel (Scomber japonicus), anchovy (Engraulis mordax), threadfin herring (Opisthonema libertate), herring (Harengula thrissina), schooling carangids (Decapterus macrosoma), hake (Merluccius angustimanus), lantern fishes (Triphoturus mexicanus and other myctophids), and neritic squids (Lolliguncula panamensis, Loliolopsis diomedae; Gallo-Reynoso 1991; Niño-Torres et al. 2006; Gallo-Reynoso unpublished data).

The fact that dolphins are born with a permanent set of teeth (Myrick 1991) allows determining the approximate age of a particular individual with a high degree of accuracy. The technique for aging marine mammals consists on the counting of dentinal layers present on the teeth. This strategy has been used for aging large-toothed animals such as the California sea lions, Zalophus californianus (Tovar-Aguilar 1989), the sperm whale Physeter macrocephalus, and other cetaceans (Scheffer and Myrick 1980), the bottlenose dolphin Tursiops truncatus (Hohn 1990), and the short-finned pilot whales Globicephala macrorhynchus (Kasuya and Matsui 1984; Égido-Villarreal 1989); the teeth of these species have been used to obtain reliable measure of age (Hohn 1980; Kimura 1980; Hohn 1990). The aim of this study is to accurately estimate the age of long-beaked common dolphins from the Gulf of California on the base of counting dentinal layers. 


\section{Methods}

All analyzed specimens were found dead and stranded on beaches of the Gulf of California, Mexico (Fig. 1). Specimens sampled included 10 males, 7 females, and 24 individuals of unknown sex (i.e. skulls from old carcasses) that are deposited in the Vertebrate Collection at Instituto Tecnológico y de Estudios Superiores de Monterrey Campus Guaymas (ITESM) and Centro de Investigación en Alimentación y Desarrollo A. C. Unidad Guaymas (CIAD). Common dolphin teeth are usually slightly curved, being the crown of the tooth directed lingually (Hui 1973); therefore we obtained teeth that were as straight as possible following Pinedo and Hohn (2000) to facilitate the reading of the growth layers. Teeth from the lower mandible were used because they are straighter and heavier than those from the upper mandible (Perrin and Myrick 1980; Hohn et al. 1989). Teeth were extracted from the mid-portion of the left mandible and prepared for age estimation. Each tooth was cleaned, freed from soft tissue, and washed with distilled water.

Figure 1. Study area and collection location of longbeaked common dolphins. Gray triangles represent the stranding area. Capital letter indicates the beaches where dolphins were found: (A) Upper Gulf, (B) Guaymas - Empalme, (C) Ciudad Obregon, (D) Tastiota, and (E) Puertecitos, Baja California.

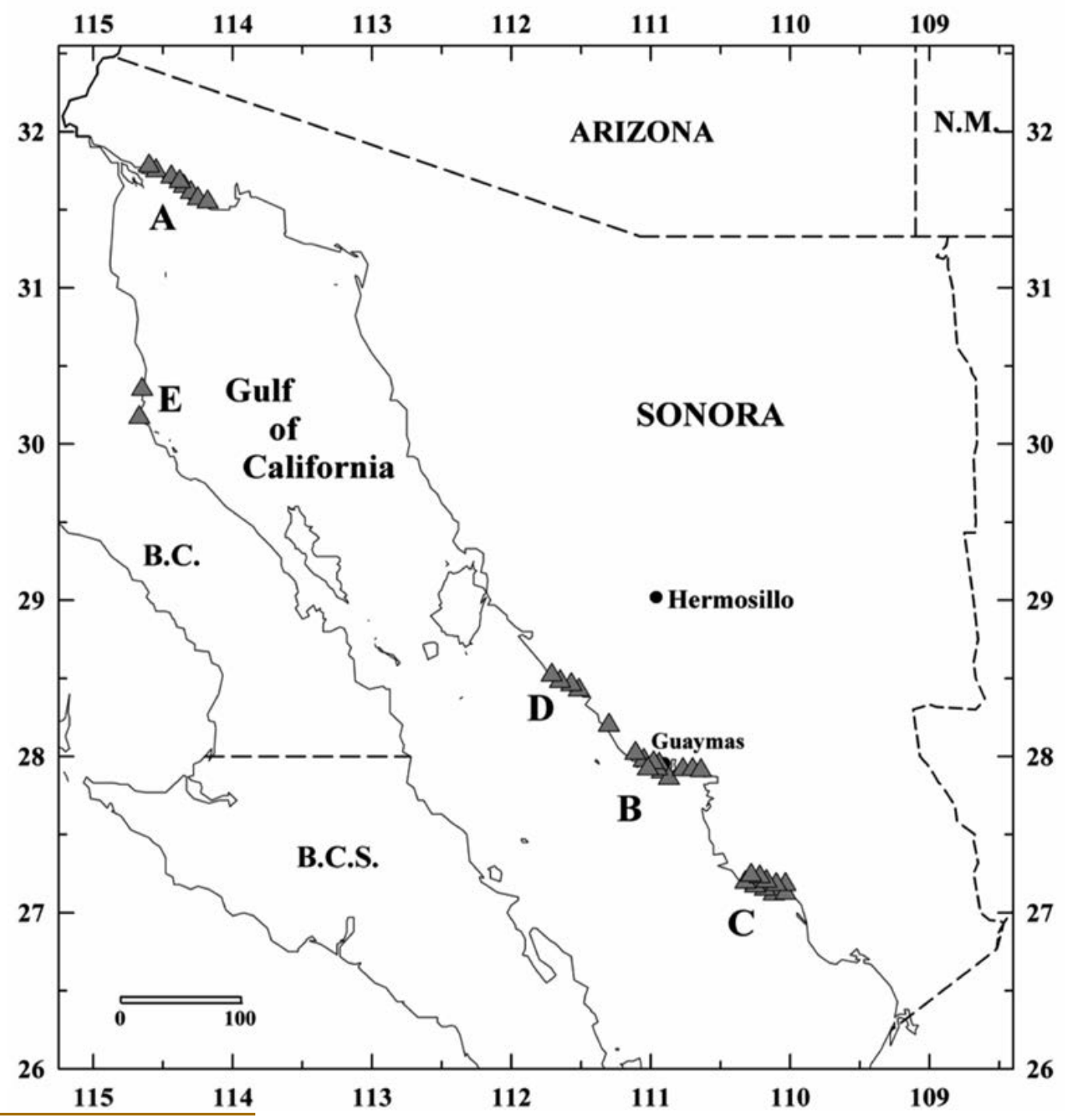


Estimating age in D. capensis was done with the method described by Hohn (1980) modified as follows. Teeth were prepared and half-etched; they were grinded and polished with sandpaper (grit 220-600) until pulp cavity became fully exposed at midlongitudinal cut. Teeth were demineralized in $5 \%$ formic acid for 1-2 hours, which is the necessary time for the teeth to acquire a rubbery consistence; times longer than two hours may cause the destruction of the teeth by the acid; to avoid this, demineralization was monitored with acetone to buffer the reaction. Teeth were rinsed in distilled water and allowed to dry. Acid-etching reveals dentinal teeth layering pattern as valleys and ridges (Hohn 1980; Pierce and Kajimura 1980). These layers form groups called Growth Layer Groups (GLGs; Perrin and Myrick 1980). Due to GLGs small size (tooth $=3-4$ $\mathrm{mm} ; 0.3-0.4 \mathrm{~g}$ ), teeth were adhered to a microscope slide to observe them. GLGs were counted and photographed using a Fisher Stereomaster II Microscope (30-60x magnification).

Four different readers (with no experience in reading GLGs, including two of the authors) assisted to obtain the age estimate for each dolphin (each tooth was read four times by the same person, thus 164 readings for each person were done for the whole set, totaling 656 readings. Readings were inconsistent at the beginning, but at the end of GLGs counts, estimated ages were accepted by consensus). The following guidelines were used for estimating age: A GLG consists of one valley and one prominent ridge. Accessory layers found within each GLG appear as less prominent ridges. The pulp cavity size gets smaller as the individual gets older and subsequent GLGs get thinner; thus, it becomes more difficult to age older animals (Hohn 1990).

Growth layer deposition in common dolphins (D. delphis) occurs annually (Gurevich et al. 1980; Hohn 1990) therefore we assumed that in long-beaked common dolphin $D$. capensis, one GLG also will be formed each year.

Dolphin age categories were defined as follows: nursing calves (recently born to 18 months or 1.5 years), juveniles (2-7 years, according to Reddy et al. (1991) for $T$. truncatus), subadults (7-12 years of age, according to Perrin and Reilly (1984) for $D$. delphis), and adults (12 years of age or more). Individuals which their body standard length was measured and their skull was collected by Vidal and Gallo-Reynoso (1996, 2012) in the mass stranding of January 1995, were used to estimate age categories for this study; these specimens were categorized as a new born male calf (ITESM-CIAD-950225), a juvenile female (ITESM-CIAD-950128-4), a subadult male (ITESM-CIAD-950331-3), an adult female (ITESM-CIAD-950331-2), and an adult male (ITESM-CIAD-950331-1). Other individuals on the sample have documented measurements in the field and were available on the collection vouchers; therefore we used that data to establish a regression between age and standard length. To investigate the age-length relationship on this species a regression between age and standard length was performed.

Of the 41 dolphins, only 15 individuals were measured and sexed in the field ( 6 calves, 6 subadults and 3 adults) and able to be used in the age-length relationship; the other dolphins on the sample $(n=26)$ were collected as carcasses on the beach and were not used for this age-length relationship. Cause of death was determined by the markings on the stranded dolphin bodies and registered on the collection vouchers. 


\section{Resullts}

Delphinus capensis age. Breakdown of age category estimates were: 17 individuals, $41.5 \%$, correspond to adults (12-21 GLGs); 10 individuals, $24.4 \%$, were subadults (712 GLGs); 10 individuals, $24.4 \%$, were juveniles (2-7 GLGs); and 4 individuals, $9.7 \%$, were nursing calves ( $<1$ GLG) (Fig. 2 and 3). Larger dolphins were found to be the older ones: the longest male $(264.7 \mathrm{~cm})$ was 21 year old and longest female $(252.4 \mathrm{~cm})$ was 18 year old (Table 1$)$.

Figure 2. Age estimates for stranded Delphinus capensis from Sonora, México. GLGs = Growth Layer Groups. Note two individuals from Baja California $\quad(<1 \quad$ GLG, 5 GLG; $n=41)$.

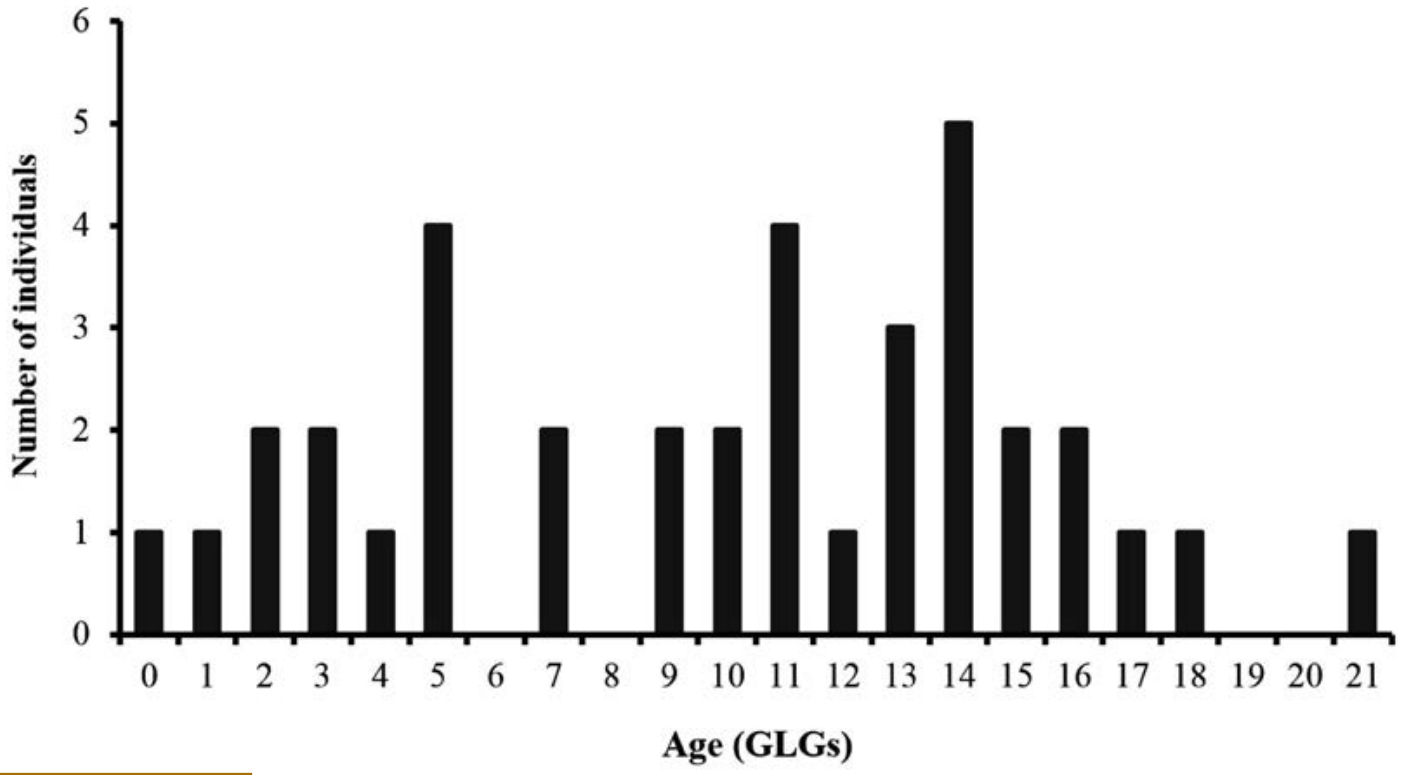

Relationship between age and total length. The estimated ages of individuals whose skull were collected in the mass stranding of January 1995 (Vidal and Gallo-Reynoso 1996, 2012), which were used to estimate age categories for this study were confirmed as: A 0 year (yr.) old male calf (ITESM-CIAD-950225), a 5 yr. old juvenile female (ITESMCIAD-950128-4), a 10 yr. old subadult male (ITESM-CIAD-950331-3), an 18 yr. old adult female (ITESM-CIAD-950331-2), and a 21 yr. old adult male (ITESM-CIAD-950331-1). Independent of the sex of common dolphins, the obtained regression was significant with an $\mathrm{r}^{2}=0.7068, P<0.001$ (Age $=5.7736^{\mathrm{E}-008}$ (Length) ${ }^{3.5189} ;$ Fig. 4$)$.

Cause of death. Cause of death for 15 dolphins (36.6\%) that were collected as dry carcasses on different beaches is unknown. Other five dolphins (12.2\%) were collected in the Upper Gulf of California, from a mass mortality and probably died in a suspected Domoic acid poisoning that caused massive die-offs and strandings at the end of 1994 and the beginning of 1995 (Vidal and Gallo-Reynoso 1996), and was repeated in a minor scale in 2004 in the Upper Gulf of California (Gallo-Reynoso et al. 2004). A total of 21 dolphins (51.2\%) of all ages died in fisheries related incidents, 19 of them in gillnet, representing a major threat for long-beaked common dolphins in the Gulf of California; one died incidentally in the trawl net of a shrimp boat, and the other was killed in a sardine fishing operation. 


\begin{tabular}{|c|c|c|c|c|c|c|c|}
\hline Individual & Collection code & $\begin{array}{l}\text { Year of } \\
\text { collection }\end{array}$ & Age & $\begin{array}{l}\text { Age } \\
\text { Category }\end{array}$ & Geographic area & Sex & $\begin{array}{l}\text { Size } \\
(\mathrm{cm})\end{array}$ \\
\hline 1 & ITESM-811208 & 1981 & 3 & Juvenile & B & M & 203.8 \\
\hline 2 & ITESM-820000-1 & 1982 & 9 & Subadult & $\mathrm{B}$ & ND & $200^{*}$ \\
\hline 3 & ITESM-840429-2 & 1984 & 11 & Subadult & $\mathrm{C}$ & ND & $210^{*}$ \\
\hline 4 & ITESM-840429-4 & 1984 & 11 & Subadult & $\mathrm{C}$ & M & 213 \\
\hline 5 & ITESM-840429-5 & 1984 & 14 & Adult & $\mathrm{C}$ & ND & $230^{*}$ \\
\hline 6 & ITESM-840429-6 & 1984 & 4 & Juvenile & $\mathrm{C}$ & $\mathrm{F}$ & $175^{*}$ \\
\hline 7 & ITESM-840429-7 & 1984 & 13 & Adult & $\mathrm{C}$ & $\mathrm{F}$ & 215 \\
\hline 8 & ITESM-840429-8 & 1984 & $14+1$ & Adult & $\mathrm{C}$ & $\mathrm{F}$ & $240^{*}$ \\
\hline 9 & ITESM-840429-9 & 1984 & 15 & Adult & $\mathrm{C}$ & ND & $240^{*}$ \\
\hline 10 & ITESM-840429-10 & 1984 & 14 & Adult & $\mathrm{C}$ & ND & $230^{*}$ \\
\hline 11 & ITESM-840429-11 & 1984 & 15 & Adult & $\mathrm{C}$ & ND & $240^{*}$ \\
\hline 12 & ITESM-840429-12 & 1984 & 5 & Juvenile & $\mathrm{C}$ & ND & $180^{*}$ \\
\hline 13 & ITESM-841100 & 1984 & 13 & Adult & B & ND & $220^{*}$ \\
\hline 14 & SN1 & 1985 & 16 & Adult & $\mathrm{B}$ & ND & $247^{*}$ \\
\hline 15 & SN5 & 1985 & 11 & Subadult & $\mathrm{B}$ & ND & $210^{*}$ \\
\hline 16 & ITESM-850502-2 & 1985 & 17 & Adult & B & ND & $250^{*}$ \\
\hline 17 & ITESM-860320 & 1986 & 3 & Juvenile & B & $\mathrm{F}$ & 187 \\
\hline 18 & ITESM-860428-1 & 1986 & 5 & Juvenile & A & ND & $180^{*}$ \\
\hline 19 & ITESM-860428-4 & 1986 & 2 & Calf Nursing & A & ND & $160^{*}$ \\
\hline 20 & ITESM-860429-2 & 1986 & 11 & Subadult & A & ND & $210^{*}$ \\
\hline 21 & ITESM-860429-3 & 1986 & 9 & Subadult & A & ND & $200^{*}$ \\
\hline 22 & ITESM-860429-4 & 1986 & 10 & Subadult & A & ND & $208^{*}$ \\
\hline 23 & ITESM-860429-5 & 1986 & $12+1$ & Adult & A & ND & $230^{*}$ \\
\hline 24 & ITESM-860510 & 1986 & 1 & Calf Nursing & B & M & 164.5 \\
\hline 25 & ITESM-860529 & 1986 & 16 & Adult & B & ND & $247^{*}$ \\
\hline 26 & ITESM-880120 & 1988 & 12 & Adult & B & ND & $225^{*}$ \\
\hline 27 & ITESM-880426 & 1988 & $3+1$ & Juvenile & $\mathrm{B}$ & M & 201 \\
\hline 28 & ITESM-900223-2 & 1990 & 7 & Subadult & $\mathrm{D}$ & ND & 168.5 \\
\hline 29 & ITESM-900223-3 & 1990 & 13 & Adult & $\mathrm{D}$ & M & 212.7 \\
\hline 30 & ITESM-900223-8 & 1990 & 12 & Subadult & $\mathrm{D}$ & ND & 258 \\
\hline 31 & ITESM-900223-10 & 1990 & 14 & Adult & $\mathrm{D}$ & M & 227 \\
\hline 32 & ITESM-900223-11 & 1990 & 9 & Subadult & $\mathrm{D}$ & ND & 180 \\
\hline 33 & ITESM-900326 & 1990 & $6+1$ & Juvenile & ND & ND & $196^{*}$ \\
\hline 34 & ITESM-940128 & 1994 & 5 & Juvenile & B & M & $180^{*}$ \\
\hline 35 & ITESM-941207 & 1994 & 7 & Juvenile & B & $\mathrm{F}$ & $196^{*}$ \\
\hline 36 & ITESM-950128-4 & 1995 & 5 & Juvenile & E & $\mathrm{F}$ & $180^{*}$ \\
\hline 37 & ITESM-950225 & 1995 & 0 & Calf Nursing & E & M & 163 \\
\hline 38 & ITESM-950319 & 1995 & 2 & Calf Nursing & A & M & 170 \\
\hline 39 & ITESM-950321-3 & 1995 & 10 & Subadult & $\mathrm{B}$ & M & $208^{*}$ \\
\hline 40 & ITESM-950331-1 & 1995 & 21 & Adult & A & M & 264.7 \\
\hline 41 & ITESM-950331-2 & 1995 & 18 & Adult & A & $\mathrm{F}$ & 252.4 \\
\hline
\end{tabular}

Table 1. Age categories were estimated by dentinal growth layer groups (GLGs) on common dolphin, $D$. capensis specimens collected in the Gulf of California.
Abbreviations: $M=$ male, $F=$ female, ND $=$ not determined or no data available, $\mathrm{SN}=$ no code number available at the collection, and area of collection: $A=$ Golfo de Santa Clara, B = Guaymas, $\mathrm{C}=$ Ciudad Obregón, $\mathrm{D}=$ Tastiota, $\mathrm{E}=$ Baja California.

*Calculated length of estimated age common dolphins ( \pm 1 SD). 


\section{Discussion}

Age at weaning and age at sexual maturity have not been determined for long-beaked common dolphins in the Gulf of California. The age categorization (calf, juvenile, and adult) that we used here were obtained from previous short-beaked common dolphin, D. delphis, studies in captivity, stranded individuals from Southern California-Baja California, and tuna-seine operation incidental captures on the Eastern North Pacific, and Eastern Tropical Pacific (Hui 1973; Evans 1975; 1994).

Figure 3. Dentinal layering observed in the half-etched teeth of long-beaked common dolphins (Delphinus capensis); sample of four different individuals from the present study. Each line marks a Growth Layer Group (GLG). PD $=$ prenatal dentine, $\mathrm{NL}$ $=$ neonatal line, $\mathrm{AL}=$ accessory layer, $\mathrm{PC}=$ pulp cavity, inc = incomplete GLG. a) Individual ITESMCIAD880426: estimated age: $3+1$ inc GLG, estimated age: 3.8 years old (mid-longitudinal section). b) Individual ITESM-CIAD900326: estimated age: $6+1$ inc GLG, known age: 6.2 years old (mid-longitudinal section, upper part "offcenter"). C) Individual ITESM-CIAD 860429-5: estimated age: $12+1$ inc GLG. d) Individual ITESMCIAD840429-8: estimated age: 15 GLG, known age: 14-16 years old (slightly "off-center" section).

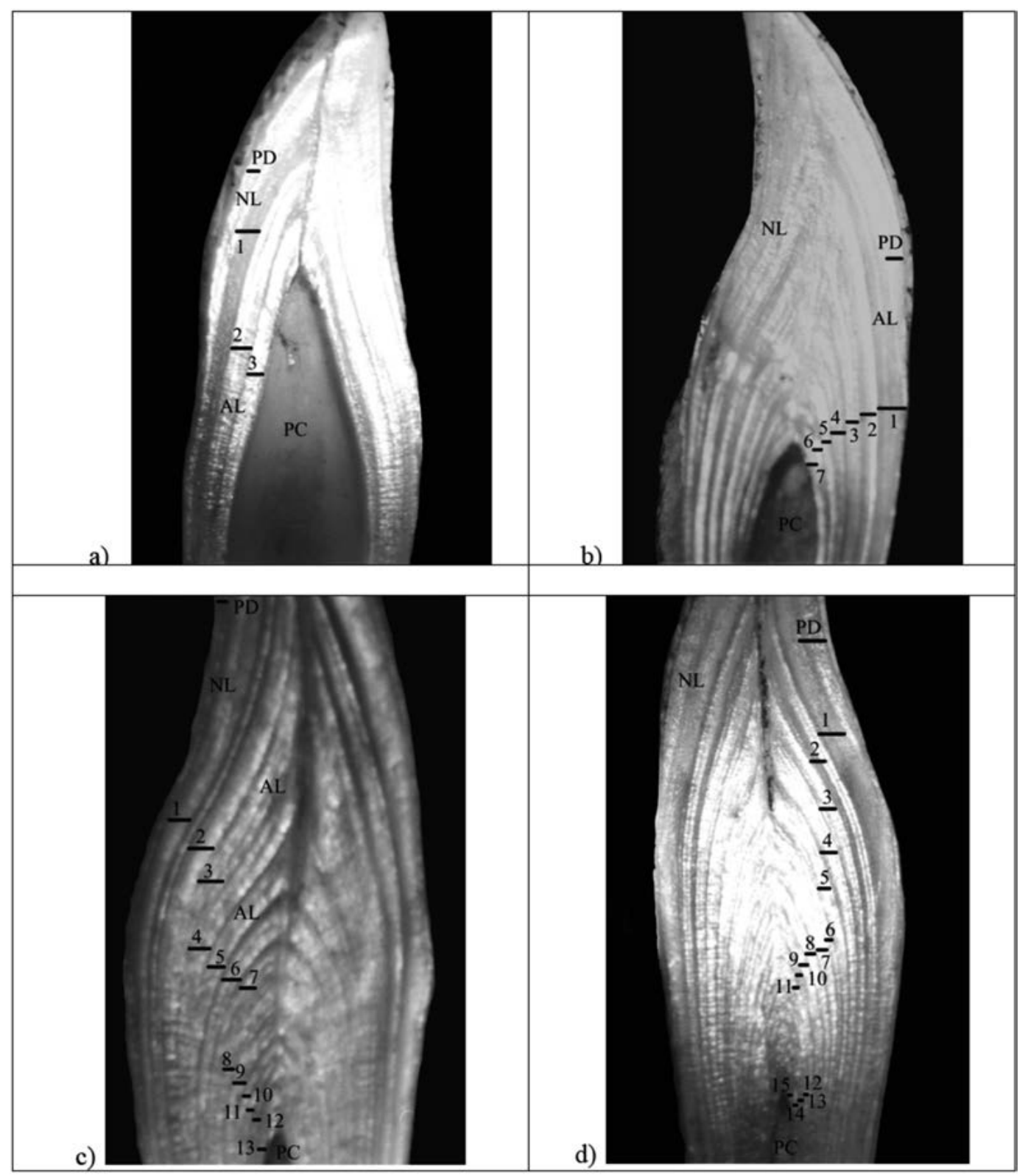

Closure of the pulp cavity prevents precise age estimates from dentinal layering of older dolphins, due that GLGs become thinner and thus difficult to read; as such, teeth layering in common dolphins are "deceptive" (A. Hohn per. com. to E. Francisco 1998). Gurevich et al. (1980) found pulp cavity closure to occur in D. delphis between 10-12 GLGs. This 
may explain the high number of individuals that we determined with 11,13 , and 14 GLG counts. Although there were four readers, age estimates may be a little biased.

Relevant information such as sex, length, and other stranding records were not available for the majority of individuals in this study (sex for 23 individuals; length for 26 individuals); 10 specimens were found as bleached, partial skeleton and /or complete skull (including mandibles and tympanic bullae). Only 15 individuals of the sample presented information on sex and length. This lack of information prevented obtaining a better set of data for the age - length relationships.

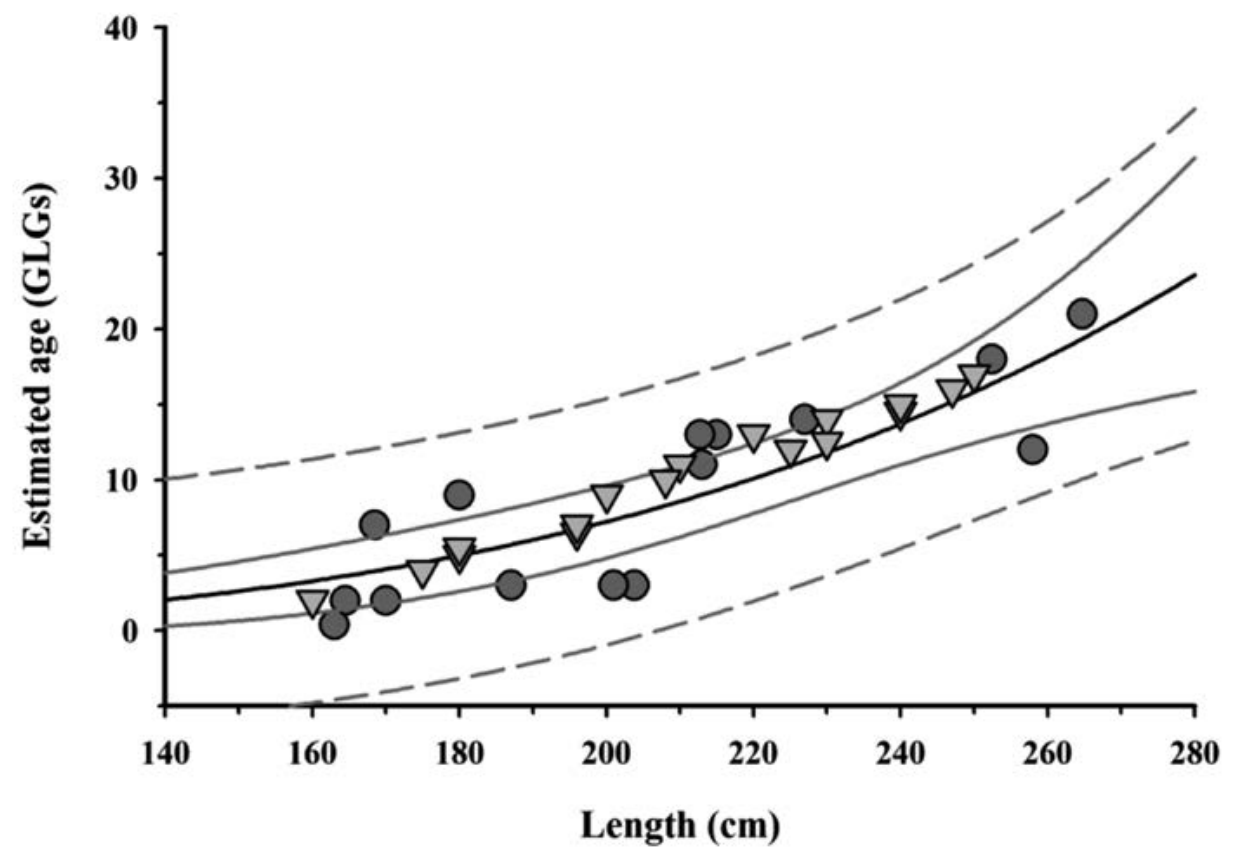

Figure 4. Age - length relationships for Delphinus capensis $(n=15$ solid circles), although the small sample size the regression is significant $\left(y=5.7736^{\mathrm{E}}\right.$ ${ }_{008}(\mathrm{X})^{3.5189} ; \mathrm{r}^{2}=0.7068, P<$ $0.0001)$, the estimated age of the other stranded longbeaked common dolphins in the sample were plotted (inverted triangles), showing that their estimated age/length fall within the $95 \%$ confidence band (solid line) and well within the $95 \%$ prediction band (dashed line); therefore the relationship between age/length is suitable to determine the probable age at certain length and vice versa.

We imply that long-beaked dolphins and common dolphins are ecological equivalents, their distribution seasonally overlap in the Southern and Central Gulf of California and in the Pacific coast of Baja California. They may have similar growth rates and dentinal deposition which are not yet known in the long-beaked common dolphins, even though long-beaked common dolphins present larger sizes, i. e. an 18 year old female of 252.4 cm (Vidal and Gallo-Reynoso 1996, 2012) compared to a short-beaked female of 25 year old from the eastern north Pacific with a length of $197.2 \mathrm{~cm}$ (Chivers and Danil 2007). This difference in size might contradict that both species are ecological equivalents. A study of age at weaning and at sexual maturity in long-beaked common dolphins from the Gulf of California is highly desirable.

New studies might find that age estimates can provide insights into fishery effects on D. capensis in the Gulf of California; small pelagic fisheries are a potential source of environmental depletion of seabird, marine mammals and fishes' food in the Gulf of California (Velarde et al. 2004), and a probable cause of long-beaked common dolphin deaths in the Gulf of California (Gallo-Reynoso 2003). Would there be a change in age composition of long-beaked common dolphin populations due to an indirect effect of fisheries? Our small sample size results do not accurately describe $D$. capensis mortality due to fisheries in the Gulf of California. 
Future studies would also clarify the degree of vulnerability of long-beaked common dolphins to toxic algae that accumulate in small pelagic fishes and seems to have produced mass strandings in the Upper Gulf (Gallo-Reynoso et al. 2004; Sierra-Beltrán et al. 2005). It is important to note that assisted dolphins by volunteers during this mass stranding survived the effects of poisoning and where returned to the sea; of 78 individuals stranded only 28 died (Bryant 2004). The effects of biomagnification of man-made toxins used for agriculture, on long-beaked common dolphins in the environment, due to the ingestion of small pelagic fishes that accumulates these toxins has only been monitored for DDT and its metabolites (Gallo-Reynoso et al. 2014), their probable contamination with other long term toxic compounds (i. e. PCBs) should be evaluated and monitored.

\section{Acknowledgments}

We thank the MIRT-UCSC-CIAD grant to E. O. Francisco (1998-2000), and to the project that allowed us to obtain and process the teeth extracted from long beaked common dolphins of the vertebrate collection of ITESM-CIAD Guaymas. We thank A. A. Hohn for her guidance and thoughtful comments in the various stages of the project. We thank D. Ibarra and J. Égido that helped reading the GLG's. We are also indebted to three anonymous reviewers which suggestions greatly improved the manuscript.

\section{Literature cited}

Átvarez-Borrego, S. 1983. Gulf of California. Pp. 427-446 in Ecosystems of the World. (Ketchum, B. H. ed.). Elsevier Scientific. New York, USA.

Bryant, E. H. 2004. Dolphin rescue, Bahía San Jorge. CEDO News - Noticias del CEDO 10:24-27.

Chivers, S. J., AND K. Danit. 2007. Growth and reproduction of female short-beaked common dolphins, Delphinus delphis, in the eastern tropical Pacific. Canadian Journal of Zoology 85:108-121.

ÉGido-Villarreal, J. 1989. Algunos aspectos biológicos de dos grupos de calderones (Globicephala macrorhynchus Gray, 1846) (Cetacea: Delphinidae) varados en costas Mexicanas. Tesis Profesional. Facultad de Ciencias, Universidad Nacional Autónoma de México. Ciudad de México, México.

Evans, W. E. 1975. Distribution, differentiation of populations, and other aspects of the natural history of Delphinus delphis Linnaeus in the northeastern Pacific. Ph.D. Thesis. University of California Los Angeles. Los Angeles, USA.

Evans, W. E. 1994. Common dolphin, White-bellied porpoise Delphinus delphis Linnaeus, 1758. Vol. 4. Pp. 191-224 in Handbook of Marine Mammals (Ridgway, S. H., and R. J. Harrison eds.). Academic Press. London, United Kindom.

Gallo-Reynoso, J. P. 1990. The Gulf of California common dolphin. Whale watcher Journal of the American Cetacean Society 24:7-8.

Gallo-Reynoso, J. P. 1991. Group behavior of common dolphins (Delphinus delphis) during prey capture. Anales Instituto de Biología, Serie Zoología 62:253-262.

Gallo-Reynoso, J. P. 1998. Distribución y movimientos estacionales del delfín común, Delphinus capensis, en el Golfo de California. Abstract in: XXIII Reunión Internacional para el Estudio de los Mamíferos Marinos. Playa del Carmen, Quintana Roo. Abril 20 a 24. Available at: jpgallo@ciad.mx 
Gallo-Reynoso, J. P. 2003. Mortandad de mamíferos marinos en el área de Guaymas debido a la interacción con las pesquerías. Centro de Investigación en Alimentación y Desarrollo, A.C., Unidad Guaymas. Unpublished document, available at: jpgallo@ciad.mx

Gallo-Reynoso, J. P., and B. Alessio. 1989. Ecology of the common dolphin, Delphinus delphis (Linnaeus, 1758), in the Gulf of California . Abstract in: Eighth Biennial Conference on the Biology of Marine Mammals. Pacific Grove, California. December 7-11. Available at: jpgallo@ciad.mx

Gallo-Reynoso, J. P., J. Égido-Villarreal, A. Sierra-Beltrán, M. P. Blanco-Parra and C. A. Niño-Torres. 2004. Possible causes of the stranding of long-beaked common dolphins (Delphinus capensis) in the Gulf of California. CEDO News - Noticias del CEDO 10:28-29.

Gallo-Reynoso, J. P., T. B. Malek, J. García-Hernández, L. Vázquez-Moreno and I. SeguraGarcía. 2014. Concentrations of DDE in blubber biopsies of free-ranging longbeaked common dolphin (Delphinus capensis) in the Gulf of California. Bulletin of Environmental Contamination and Toxicology (In press).

Gurevich, V. S., B. S. Stewart, and L. H. Cornell. 1980. The use of tetracycline in age determination of common dolphins, Delphinus delphis. Reports of the International Whaling Commission (Special Issue 3):165-170.

Hoнn, A. A. 1980. Analysis of growth layers in the teeth of Tursiops truncatus using light microscopy, microradiography, and SEM. Reports of the international whaling commission (Special Issue 3):155-160.

НонN, А. А. 1990. Reading between the lines: Analysis of age estimation in dolphins. Pp. 575-585 in The bottlenose dolphin (Leatherwood, S., and R. R. Reeves, eds.) Academic Press. New York, USA.

Hohn, A. A., M. D. Scott, R. S. Wells, J. C. Sweeney, and A. B. Irvine. 1989. Growth layers from known-age, free-ranging bottlenose dolphins. Marine Mammal Science 5:315-342.

Kasuya, T., and S. Matsui. 1984. Age determination and growth of the short-finned pilot whale off the Pacific coast of Japan. Scientific reports of the whales research institute 35:57-91.

Kımura, M. 1980. Variability in techniques of counting dentinal growth layer groups in a tooth of a known-age dolphin, Tursiops truncatus. Reports of the international whaling commission (Special Issue 3):161-163.

Mrrick, A. C. 1980. Some approaches to calibration of age in odontocetes using layered hard tissues. Reports of the international whaling commission (Special Issue 3):9597.

Mrrick, A. C. 1991. Some new and potential use of dental layers in studying delphinid populations. Pp 251-279. in Dolphin societies, discoveries and puzzles (Pryor, K. and K. S. Norris. Eds.). University of California Press. Berkeley, USA.

Niño-Torres, C. A., J. P. Gallo-Reynoso, F. Galván-Magaña, E. Escobar-Briones, and S. A. Маско. 2006. Isotopic analysis of $\delta^{13} \mathrm{C}, \delta^{15} \mathrm{~N}$ and $\delta^{34} \mathrm{~S}$ "a feeding tale" in teeth of the longbeaked common dolphin, Delphinus capensis. Marine Mammal Science 
22:831-846.

Perrin, W. F., And S. B. Reilly. 1984. Reproductive parameters of dolphins and small whales of the family Delphinidae. Pp 97-134 in Reproduction in whales, dolphins and porpoises. (Perrin, W.F., R. L. Brownell, and D. P. DeMaster. eds.). Reports of the international whaling commission (Special Issue 6).

Pierce, K., and H. Kajimura. 1980. Acid etching and highlighting for defining growth layers in cetacean teeth. Reports of the international whaling commission (Special Issue 3):99-103.

Pinedo, M. C., ANd A. A. Hohn. 2000. Growth layer patterns in teeth from the Franciscana, Pontoporia blainvillei: Developing a model for precision in age estimation. Marine Mammal Science 16:1-27.

Reddy, M., T. Kamolnick, D. SkaAr, C. Curry, and S. Ridgway. 1991. Bottlenose dolphins: Energy consumption during pregnancy, lactation and growth. Proceedings of Annual Conference of International Marine Animal Trainer Association. Available at: http://www.nosc.mil/sti/publications/reprints/marinemammals/.

Scheffer, V. S., AND A. C. Myrick. 1980. A review of studies to 1970 of growth layers in the teeth of marine mammals. Reports of the international whaling commission (Special Issue 3):51-63.

Sierra-Beltrán, A. P., R. Cortés-Altamirano, J. P. Gallo-Reynoso, S. licea-Durán, and J. Égido-Villarreal. 2005. Is Pseudo-nitzschia pseudodelicatissima toxin the principal cause of sardines, dolphins, sea lions and pelicans mortality in 2004 in Mexico? Harmful Algae News. The Intergovernmental Oceanographic Commission of UNESCO 29:6-8.

Silber, G. K., M. W. Newcomer, P. C. Silber, H. Pérez-Cortés, and G. M. Ellis. 1994. Cetaceans of the northern Gulf of California: distribution, occurrence and relative abundance. Marine Mammal Science 10:283-298.

Tovar-Aguilar, F. 1989. Contribución al conocimiento del desarrollo ontogénico del cráneo del lobo marino macho de California (Zalophus californianus californianus, Lesson 1828) (Pinnipedia: Otariidae). Tesis de Licenciatura. Facultad de Ciencias, Universidad Nacional Autónoma de México. Ciudad de México, México.

Velarde, E., E. Ezcurra, M. A. Cisneros-Mata, and M. F. Lavín. 2004. Seabird ecology, El Niño anomalies, and prediction of sardine fisheries in the Gulf of California. Ecological Applications 14:607-615.

Vidal, O., L. T. Findley, and S. Leatherwood. 1993. Annotated checklist of marine mammals of the Gulf of California. Proceedings of the San Diego Society of Natural History 28:1-16.

Vidal, O., AND J. P. Gallo-Reynoso. 1996. Die-offs of marine mammals and sea birds in the Gulf of California, Mexico. Marine Mammal Science 12:627-635.

Vidal, O., AND J. P. Gallo-Reynoso. 2012. Composition by sex and size of long-beaked common dolphin (Delphinus capensis) from a die-off in the Gulf of California, México. Marine Biodiversity Records doi:10.1017/S17552672120003956; 5:1-3; e82; 2012 Published online. 
Sometido: 29 de marzo de 2014

Revisado: 16 de junio de 2014

Aceptado: 24 de agosto de 2014

Editor asociado: Guillermo D'Elia

Diseño gráfico editorial: Gerardo Hernández 